\title{
Recenzja: Joanna Dziadowiec-Greganić, Agnieszka Dudek: Handmade in Wiśniowa Wiśniowsko rócno robota \\ O najbardziej materialnym $z$ niematerialnych aspektów dziedzictwa kulturowego \\ w pogranicznej gminie Wiśniowa. Wiśniowa-Wrocław, Gminny Ośrodek Kultury i Sportu w Wiśniowej - Polskie Towarzystwo Ludoznawcze, 2019 (Archiwum Etnograficzne. T. 63), 400 stron
}

Recenzowana książka, autorstwa Joanny Dziadowiec-Greganić i Agnieszki Dudek, oraz Pawła Pawlaczyka, który opracował rozdział traktujący o gorsetach, jest jednym $\mathrm{z}$ efektów szerszego, holistycznie potraktowanego projektu „Wiśniowski jarmark rzemiosł i zawodów tradycyjnych - lokalna tradycja w działaniu", realizowanego w latach 2018-2019. Na ten wielowymiarowy projekt złożyły się ponadto między innymi: internetowa interaktywna mapa tradycyjnych profesji; wystawa fotograficzna „Wiśniowskie dziedzictwo w dawnym obiektywie"; tematyczne spoty i film Handmade in Wiśniowa; multimedialny, wirtualny i „tradycyjny” (w postaci kart inwentarzowych) katalog gorsetów z terenu gminy; konferencje i debaty oraz animacyjne spotkania praktyków i teoretyków; tematyczne widowiska współtworzone przez różne pokolenia mieszkańców działających w lokalnym ruchu artystycznym, folklorystycznym; wieńczący projekt jarmark, który w zamierzeniu jego organizatorów bazował na wspomnianych dawnych, cyklicznych jarmarkach i targach wiśniowskich.

Książka składa się z odautorskiego wstępu, wykazu skrótów, wprowadzenia, siedmiu rozdziałów, z których każdy jest podzielony na kilka lub kilkanaście podrozdziałów, postscriptum, streszczenia $\mathrm{w}$ języku angielskim, bibliografii, wy- 
kazu źródeł internetowych, spisu rysunków, spisu fotografii, spisu tabel, indeksu osobowego. Swoje uwagi zacznę od tytułu, a raczej podtytułu pracy, gdyż mam zastrzeżenia do stwierdzenia, że gmina Wiśniowa jest „pograniczna”. Autorki co prawda usiłują wyjaśnić, że owa pograniczność ma charakter etnograficzny, gdyż gmina ta zlokalizowana jest na styku kilku regionów etnograficznych. Jednakże już we wstępie wspominają, że to z powodu letargu czy wręcz ,ignorancji badawczej" etnografów (akademików i muzealników) obszar ten jest etnograficzną białą plamą, a tutejsi mieszkańcy nie godzą się z utartymi kategoryzacjami ich mikroregionu. Autorki, ulegając autorytetom tradycyjnych etnografów, akceptujących substancjalną kategoryzację kultury ludowej („świata chłopów/wieśniaków”), zdają się nie dostrzegać, że zamiana terminu "przejściowy” na „pograniczny” to jedynie „(z)ryncno" gra słów. Swoją drogą mamy tu do czynienia $\mathrm{z}$ interesującym przykładem artefaktów etnograficznych, a sam wiśniowski mikroregion jest znakomitym terenem do przeprowadzenia badań nad grupową tożsamością i kulturowymi dystansami.

Autorki, słusznie zauważając, że wielokontekstowe i wielowymiarowe badania dziedzictwa kulturowego oraz działania animacyjne na jego rzecz od pewnego czasu cieszą się na świecie szerokim zainteresowaniem, dodają, iż tendencje te obserwuje się $\mathrm{w}$ ostatnich latach również $\mathrm{w}$ Polsce. Trudno zgodzić się $\mathrm{z}$ taką diagnozą. Już bowiem na początku XIX wieku Stanisław Staszic apelował do polskiej młodzieży o poznawanie i zachowywanie dziedzictwa kulturowego, jako ważnego warunku utrzymania narodowej tożsamości. Przez następne kilkadziesiąt lat narodowej niewoli o zachowanie ludowej (w znaczeniu - narodowej) tradycji zabiegali między innymi ludoznawcy i etnografowie. Na przełomie XIX i XX stulecia ideolodzy regionalizmu widzieli w kulturowym dziedzictwie podstawę odrodzenia polskiej narodowości, postulując pielęgnowanie przeszłości i rozwijanie starych form, a jednocześnie dostosowywanie ich do nowych potrzeb. Władysław Orkan głosił, że tradycja - będąca godnością, dumą, szlachectwem synów chłopskich - jest fundamentem, na którym może powstać gmach przyszłości. Współcześni uczeni uważają, że wrażliwość na tradycję, zdolność do jej przejmowania i kontynuowania, zrozumienie dla znaczenia dziedzictwa przeszłości, jest cechą charakterystyczną ludzkości. Na konieczność zachowywania własnego dziedzictwa kulturowego zwracał również wielokrotnie uwagę Jan Paweł II. Troska o tradycję, której Handmade in Wiśniowa... jest jednym z rozlicznych przykładów, stanowi realizację tych postulatów.

Nie będąc niczym zupełnie nowym, jest jednak pewnym novum. Oryginalność tej pracy postrzegam na przykład w podmiotowej inicjatywie jej powstania, lokalnej skali opracowania, przyjętej narracji, która ma ukazać lokalne dziedzictwo w dynamicznej formie. Autorki wielokrotnie podkreślają, że to wiśniowscy liderzy lokalni, animatorzy i regionaliści postanowili zainicjować działania na rzecz ich bogatego dziedzictwa kulturowego w celu wypełnienia znaczących luk w zakresie inwentaryzacji, dokumentacji, ochrony, interpretacji i popularyzacji 
wybranego - przez samych mieszkańców - aspektu różnorodnego dziedzictwa kulturowego. Przyjęto założenie, by opracowany projekt był otwarty i przybrał formę włączającą i aktywizującą różne grupy mieszkańców całej gminy. Jednym z najważniejszych celów było działanie na rzecz umacniania tożsamości lokalnej oraz podejmowanie prób budowania wspólnotowości wokół rodzimych tradycji, płynące z przekonania o sile i znaczącej roli dziedzictwa kulturowego w życiu społecznym, religijnym, kulturalnym i ekonomicznym mieszkańców.

Jeżeli natomiast chodzi o skalę tego projektu i recenzowanego opracowania, to mam na myśli dwa wymiary: przestrzenny i zakresowy. Za godne pochwały należy uznać ograniczenie badań do obszaru gminy Wiśniowa, która chyba jednak nie jest tylko administracyjnie wyznaczonym terenem, lecz stanowi pewien mikroregion. Takie postępowanie ma uzasadnienie i odbiega od niechlubnych praktyk polegających na przeprowadzeniu - mniej czy bardziej gruntownych - badań w jednej czy dwóch miejscowościach i ekstrapolacji ich wyników na przykład na cały region (Podhale, Beskid Sądecki, Beskid Śląski itp.). Również chwalebne jest odejście od pozytywistycznego postulatu deskryptywizmu idiograficznego, czyli dążenia do maksymalnie dokładnego opisania wszystkiego. Przedmiotem realizowanego projektu oraz recenzowanej pracy są świadomie wybrane dwa wymiary lokalnego dziedzictwa kulturowego tradycyjnych zawodów, umiejętności i praktyk: produkcja wyrobów artystycznych i użytkowych oraz ich dystrybucja. Celem przeprowadzonych $\mathrm{w}$ tym zakresie badań było nie tylko stwierdzenie, jak w pamięci tutejszych mieszkańców zachowały się wyobrażenia o ginących zawodach i tradycyjnych jarmarkach, ale także podjęcie próby ich reaktywacji, które mogłyby zaktywizować i zintegrować przedstawicieli różnych grup twórców i odbiorców. Okazuje się, że badacze oraz badani mogą wspólnie realizować pewien projekt utylitarny, gdyż pewne ginące zawody mogą i powinny nadal wytwarzać określone wyroby w celu ich zbytu i osiągnięcia zysku na jarmarkach. Takie pragmatyczne podejście jest cenne również z tego względu, że reaktywacja jarmarków mogłaby się przyczynić do zachowania różnorodnych zwyczajów, obrzędów i innych tradycyjnych zachowań z nimi związanych.

Pewną wątpliwość budzi natomiast, czy te dwie zespolone ze sobą osie wiśniowskiej opowieści rzeczywiście mogło udać się ukazać nie tyle w sposób konstatywny, statyczny, stwierdzający, ile performatywny, sprawczy i wykonawczy, tzn. w działaniu, w akcji, przez przyjętą formę bezpośredniej rozmowy z miejscowymi przedstawicielami tychże tradycyjnych praktyk. Clifford Geertz przypomniał bowiem w jednym ze swoich esejów, że „istnieje jednak pewna różnica między budowaniem domu a kreśleniem planów budowy domu, zaś czytanie wiersza o posiadaniu dzieci w małżeństwie to nie to samo, co posiadanie dzieci w małżeństwie" . Ponadto same autorki stwierdzają, że podejście performatywne

${ }^{1}$ C. Geertz: Religia jako system kulturowy. W: IDEm: Interpretacja kultur. Wybrane eseje. Przeł. M. Piechaczek. Kraków 2005, s. 114. 
$\mathrm{w}$ badaniach nad dziedzictwem kulturowym polega między innymi na przeniesieniu zainteresowań badawczych z narracji na akcję, z kontemplacji na działanie.

W niniejszej recenzji skoncentrowałem się na sprawach, w moim pojęciu, podstawowych, pomijając sprawy szczegółowe. Dodam tylko, że rozdział siódmy Wiśniowskie rozmowy rzeki... (stanowiący ponad połowę książki) może być uznany przez niektórych etnologów za zbędną tzw. materiałówę. Nie podzielam takiego poglądu, zgadzając się po raz kolejny z Geertzem, który wskazywał: „Etnograf »zapisuje« dyskurs społeczny; spisuje go. Czyniąc to, przemienia ów dyskurs z ciągu przemijających zdarzeń, istniejących jedynie w momencie, kiedy dane zajście ma miejsce, $\mathrm{w}$ relację, która będzie istnieć we własnym zapisie, i do której można będzie sięgnąć ponownie"2.

Reasumując, stwierdzam, że cały projekt oraz recenzowana praca są faktycznie udaną odpowiedzią na realną, a nie wykreowaną potrzebę mieszkańców tego swoistego mikroregionu, jakim jest gmina Wiśniowa, świadomych potrzeby wykorzystania i zrozumienia własnego dziedzictwa kulturowego.

Stanisław Weglarz

${ }^{2}$ C. GeERTz: Opis gęsty: w poszukiwaniu interpretacyjnej teorii kultury. W: IDEM: Interpretacja kultur..., s. 34 . 